\title{
A Right to Ourselves: Women's Suffrage and the Birth Control Movement-ERRATUM
}

Heather Munro Prescott* and Lauren MacIvor Thompson**

https://doi.org/10.1017/S1537781420000304. Published online by Cambridge University Press, 3 August 2020.

* Corresponding author. Central Connecticut State University. Email: prescott@ccsu.edu ** Corresponding author. Georgia State University. Email: lmacivor1@gsu.edu

The affiliation heading was omitted from the original online version of this article ${ }^{1}$. It has been added to both online and in print.

\section{Note}

1 Heather Munro Prescott and Lauren MacIvor Thompson, "A Right to Ourselves: Women's Suffrage and the Birth Control Movement," Journal of the Gilded Age and Progressive Era 19 (October 2020): 542-558. https://doi.org/10.1017/S1537781420000304.

Cite this article: Prescott HM, Thompson LMacI (2020) A Right to Ourselves: Women's Suffrage and the Birth Control Movement-ERRATUM. The Journal of the Gilded Age and Progressive Era 19, 685-685. https://doi.org/10.1017/S1537781420000730 